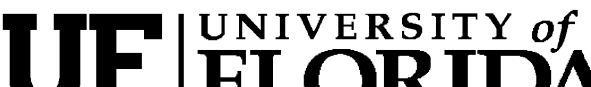 FLORIDA \\ IFAS Extension
}

\section{Pesticides and Prior Informed Consent ${ }^{1}$}

Frederick M. Fishel ${ }^{2}$

\section{Introduction}

The Prior Informed Consent (PIC) procedure is an international information exchange sponsored by the United Nations to assist countries throughout the world in decisions on whether to allow import of chemicals of concern. Some of these chemicals of concern include pesticides.

PIC maintains a listing of chemicals that have been banned or severely restricted in the participating countries because of unacceptable levels of risk to human health and/or the natural environment. At the original date of this publication, October 2009, the most current PIC list contained a total of 40 industrial and pesticidal chemicals, 29 of which are pesticide active ingredients. The PIC list is available at the following URL: http://www.pic.int/home.php?type=t\&id=29\&sid=30.

\section{U.S. Pesticide Registration and Status}

No pesticide may be lawfully sold in the United States until the U.S. Environmental Protection Agency (EPA) has reviewed the manufacturer's application for registration and determined that use of the product does not present an unreasonable risk to humans, wildlife, or the environment.

Pesticides banned in the United States are those that the EPA has determined pose an unacceptable risk. (See Figure 1.) For pesticides banned in the United States, the EPA has also determined that the unacceptable risks associated with the pesticide cannot be reduced by actions - such as label amendments - to alter use patterns. In most cases, when the EPA has banned use of a pesticide in the United States, the related active ingredients are voluntarily cancelled by the pesticide manufacturer. Table 1 contains a 1998 listing of pesticide active ingredients that have had all or most of their uses banned in the United States. (Table 1 also includes the criteria for the EPA's ban on each of these pesticide uses.) These pesticides, banned by the EPA, are included in the UN's PIC list.

Additionally, a small number of pesticides still used in the United States could be considered as banned for most practical purposes because the pesticides have only one or a few very specific lawful uses remaining. For example, the EPA has banned use of lindane for practically all of its former uses, except

1. This document is PI222, one of a series of the Agronomy Department, Florida Cooperative Extension Service, Institute of Food and Agricultural Sciences, University of Florida. Original publication date, Novmber 2009. Visit the EDIS Web site at http://edis.ifas.ufl.edu.

2. Frederick M. Fishel, associate professor, Agronomy Department, and director, Pesticide Information Office, Institute of Food and Agricultural Sciences, University of Florida, Gainesville, FL.

The Institute of Food and Agricultural Sciences (IFAS) is an Equal Opportunity Institution authorized to provide research, educational information and other services only to individuals and institutions that function with non-discrimination with respect to race, creed, color, religion, age, disability, sex, sexual orientation, marital status, national origin, political opinions or affiliations. U.S. Department of Agriculture, Cooperative Extension Service, University of Florida, IFAS, Florida A. \& M. University Cooperative Extension Program, and Boards of County Commissioners Cooperating. Interim Dean Millie Ferrer. 
for pharmaceutical use for treatment of lice and scabies. Other pesticides (not presented in Table 1) have never been registered by the EPA for use in the United States, but are in use elsewhere in the world and are included in the PIC list.

Several pesticides that have a full EPA registration are specifically regulated in Florida. (See Table 2.) Several EDIS publications address in greater detail each of the EPA-registered pesticides whose use is regulated in Florida by the Florida Department of Agricultural and Consumer Servies.

\section{Export from the United States of Unregistered Pesticides}

Pesticides that are not registered with the EPA may be lawfully manufactured in the United States and exported for use in other countries. The Federal Insecticide, Fungicide, and Rodenticide Act (FIFRA) requires that U.S. exporters of unregistered pesticides must-prior to exporting the pesticide-obtain a statement signed by the foreign purchaser indicating the purchaser's awareness that the product cannot be lawfully used in the United States. This FIFRA requirement is shipment-specific for a particular exporter, product and purchaser.

To ensure that foreign national officials responsible for the protection of health and the environment in their country are informed of such shipments, EPA transmits a copy of the statement to the Designated National Authority (DNA), a person designated in the receiving country as part of the United Nations $`$ PIC program.

The EPA places the highest possible priority on timely notification of the DNA for two categories of exported pesticides:

- Pesticides on the international PIC list, most of which have also been banned in the United States or have severely limited permitted use in the United States.

- Other pesticides banned and having limited use in the United States for health or environmental reasons, but which are not included in the PIC list.

\section{Additional Information}

Crop Protection Handbook. 2009. vol. 95. Meister Media Worldwide: Willoughby, Ohio.

Fishel, F.M. 2008. EPA approval of pesticide labeling. EDIS Publication PI167. http://edis.ifas.ufl.edu/PI203 (accessed August, 2009). Department of Agronomy, Institute of Food and Agricultural Sciences, University of Florida, Gainesville, FL.

Fishel, F.M., J.A. Ferrell, G.E. MacDonald, and B.J. Brecke. 2009. Florida's organo-auxin herbicide rule - 2009. EDIS Publication SS-AGR-12. http://edis.ifas.ufl.edu/WG051 (accessed August, 2009). Department of Agronomy, Institute of Food and Agricultural Sciences, University of Florida, Gainesville, FL.

Fishel, F.M. 2005. Specifically regulated pesticides in Florida - aldicarb. EDIS Publication PI-74. http://edis.ifas.ufl.edu/PI111 (accessed August, 2009). Department of Agronomy, Institute of Food and Agricultural Sciences, University of Florida, Gainesville, FL.

Fishel, F.M. 2005. Specifically regulated pesticides in Florida - bromacil. EDIS Publication PI-75. http://edis.ifas.ufl.edu/PI1 12 (accessed August, 2009). Department of Agronomy, Institute of Food and Agricultural Sciences, University of Florida, Gainesville, FL.

Fishel, F.M. 2007. Specifically regulated pesticides in Florida - methyl bromide. EDIS Publication PI-157. http://edis.ifas.ufl.edu/PI1 12 (accessed August, 2009). Department of Agronomy, Institute of Food and Agricultural Sciences, University of Florida, Gainesville, FL.

Fishel, F.M. 2009. Specifically regulated pesticides in Florida - organotin antifouling paints. EDIS Publication PI-179. http://edis.ifas.ufl.edu/PI215 (accessed August, 2009). Department of Agronomy, Institute of Food and Agricultural Sciences, University of Florida, Gainesville, FL.

Ware, G.W. and D.M. Whitacre. 2004. The pesticide book. 6th edition. MeisterPro Information Resources: Willoughby, Ohio. 


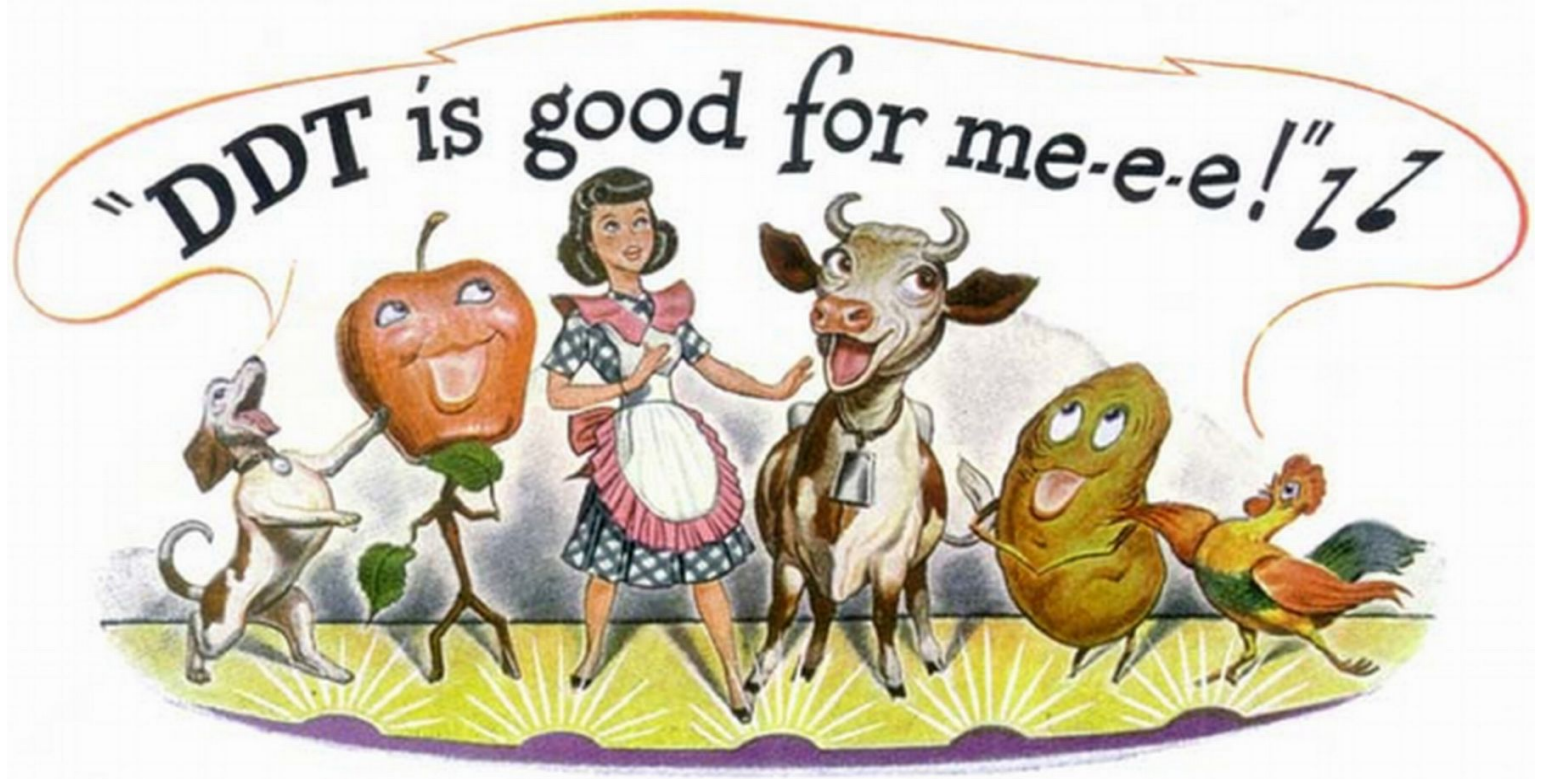

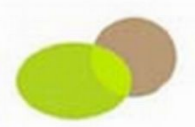

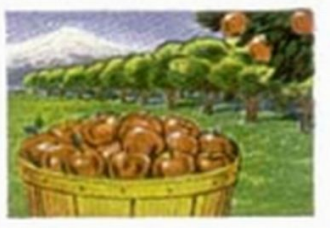

GOOD FOR FRUITS - Bigger apples, juicier fruits that are free from unsightly norms all henefits resulting frous DDT dusts and sprays.

GOOD FOR STEERS- Ifeef "row: meatie nowadays... for it s a scientific fact thatcompared to untreated cattle- beefotecr gain up to 50 pounds estra when protected from horn lies and many other pests with DD'T insecticides.

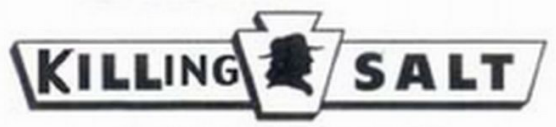

CII EM I CA LS

o7 Years" Service so Industry - Farm - Home

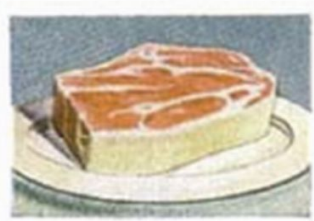

The great expectations held for DDT - been realized. During 1910 , that. when properly used, DI)T kills a Pennsalt produces DD'T and its prod. ucts in all standard forms and is now one of the country's largest producers of this amazing insecticide. Tolay, everyone can enjoy added comfort, health and safety through the insect. killing powers of Pennsalt DDT prod. uets . . and DD'T is only one of Pennsalt's many chemical products which benefit industry, faru and home.

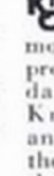

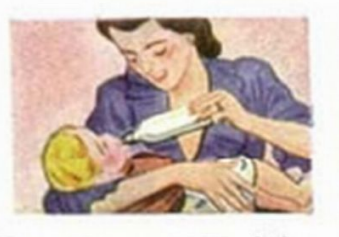

KnOX FOR THE HOME-help's Out to make liealihier. more comfortable homes... protects your family from Knos Ont DIT Powders and Sprays as direeted. the dust"!

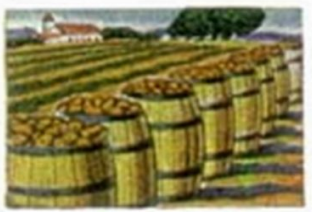

GOOD FOR ROW CROPS-2S more barris's of potatoes per act ... actual DDT teste hav. hown crop increases like this? DDT dusts and sprays help trueh farmers pass these gains along to you.

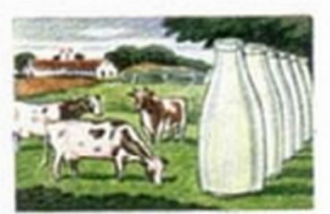

Knox FOR DAIRIES - UP to $20 \%$ more Out milk... more butter... more checse .... tests prove greater milk produetion when dairy cows are protected from the annoyance of many from the annoyance of many. insects with DDT insecti. and Barn Spray.

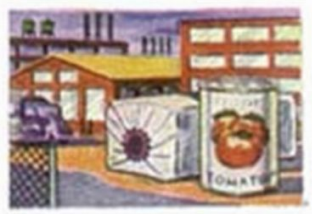

KnOXFOR INDUSTRY-Food Out procening plantr, laun. dries, dry eleaning plants. hotels dozens of industries gain effective bug control, gaine leatant workeoulitious with Penssalt DDT products.

Figure 1. In 1972, use of the pesticide DDT was banned in the United States. Credits: UF/IFAS PIO 
Table 1. Pesticide Active Ingredients Banned by the EPA for Use in the United States and Maintained on the UN's PIC List.

\begin{tabular}{|c|c|c|}
\hline $\begin{array}{l}\text { Active Ingredient } \\
\text { (Effective Date of EPA Ban.) }\end{array}$ & Use & Criteria for Ban \\
\hline 2,4,5-T (1985) & Herbicide & $\begin{array}{l}\text { The dioxin contaminant in } 2,4,5-\mathrm{T}-- \text { TCDD -- has been found } \\
\text { to be carcinogenic and to cause foetal abnormalities in } \\
\text { laboratory mice. Additionally, } 2,4,5-\mathrm{T} \text { may pose an } \\
\text { unacceptable risk of reproductive effects for pesticide } \\
\text { applicators. }\end{array}$ \\
\hline Aldrin (1974) & Insecticide & $\begin{array}{l}\text { High toxicity, persistence in the environment, especially in } \\
\text { temperate areas, and bioaccumulation of residues in the food } \\
\text { chain and in human tissues. Aldrin is variably toxic to } \\
\text { microorganisms and highly toxic to fish, crustaceans, and } \\
\text { many bird and animal species. }\end{array}$ \\
\hline Captafol (1987) & Fungicide & $\begin{array}{l}\text { Captafol was voluntarily withdrawn by the registrant. Captafol } \\
\text { is oncogenic in rats and mice; highly toxic to fish; a skin } \\
\text { sensitizer (Incidents of farm workers being disabled from its } \\
\text { effects have been reported.); moderately to very highly toxic } \\
\text { to freshwater invertebrates; found to have strong potential for } \\
\text { reproductive effects in birds; and found to cause potential } \\
\text { problems related to endangered species. }\end{array}$ \\
\hline Chlordane (1978) & Insecticide & $\begin{array}{l}\text { Chlordane's persistence and bioaccumulation in the } \\
\text { environment poses potential adverse effects to humans and } \\
\text { the environment because of continuing long-term exposure } \\
\text { through water, food and other sources. Of particular concern } \\
\text { is chlordanes demonstrated carcinogenic response in } \\
\text { laboratory rodents, as well as chlordanes potential impact on } \\
\text { human health from widespread environmental contamination } \\
\text { in the food chain. }\end{array}$ \\
\hline Chlordimeform (1988) & Insecticide/acaracide/ovicide & $\begin{array}{l}\text { Chloridimeform and its principal metabolites are considered } \\
\text { probable human carcinogens. }\end{array}$ \\
\hline Chlorobenzilate (1988) & Acaracide & $\begin{array}{l}\text { Animal studies indicated that exposure to chlorobenzilate } \\
\text { could pose risks of cancer and adverse testicular effects to } \\
\text { certain exposed groups. }\end{array}$ \\
\hline DDT (1972) & Insecticide & $\begin{array}{l}\text { The characteristics of DDT to persist, especially in temperate } \\
\text { climates, and to biomagnify in the food chain led to significant } \\
\text { reproductive effects in birds -- including the brown pelican, } \\
\text { osprey and eagles -- due to eggshell thinning. These features } \\
\text {-- combined with exposure and accumulation of residues in } \\
\text { humans and the potential oncogenicity of DDT -- contributed } \\
\text { to health concerns. In addition, there were concerns about } \\
\text { general environmental contamination of a longlived nature } \\
\text { and uncertainty about the eventual adverse impacts on } \\
\text { humans and the environment because of continuing, } \\
\text { long-term exposure through water, food and other sources. } \\
\text { Finally, DDT is toxic to a number of organisms, including fish. }\end{array}$ \\
\hline Dieldrin (1974) & Insecticide & $\begin{array}{l}\text { High toxicity to humans, fish, and many animal and bird } \\
\text { species, persistence in the environment, especially in } \\
\text { temperate areas, and bioaccumulation in the food chain and } \\
\text { in human tissues. }\end{array}$ \\
\hline Dinoseb (1986) & Defoliant/ desiccant/ herbicide & $\begin{array}{l}\text { Dinoseb and its salts have been banned because they have } \\
\text { been found in animal studies to result in high risks of birth } \\
\text { defects, male sterility, and high acute toxicity. }\end{array}$ \\
\hline
\end{tabular}


Table 1. Pesticide Active Ingredients Banned by the EPA for Use in the United States and Maintained on the UN's PIC List.

\begin{tabular}{|c|c|c|}
\hline $\begin{array}{l}\text { Active Ingredient } \\
\text { (Effective Date of EPA Ban.) }\end{array}$ & Use & Criteria for Ban \\
\hline EDB (1984) & Insecticide/nematicide & $\begin{array}{l}\text { EDB has been subject to control actions due to health } \\
\text { concerns and the persistence of the chemical in } \\
\text { groundwater. EDB has been associated with reproductive, } \\
\text { carcinogenic and genotoxic effects in addition to high acute } \\
\text { toxicity. Use as a soil fumigant has led to persistent } \\
\text { contamination of groundwater aquifers. }\end{array}$ \\
\hline Ethylene dichloride (1986) & Fumigant & $\begin{array}{l}\text { Concern about the carcinogenic properties of ethylene } \\
\text { dichloride on human health is reported as a primary reason } \\
\text { for the control actions. }\end{array}$ \\
\hline Fluoroacetamide (1980) & Rodenticide & Acute toxicity to humans, mammals, and birds. \\
\hline $\mathrm{HCH}(1978)$ & Insecticide & $\begin{array}{l}\text { Banned in the United States principally because of oncogenic } \\
\text { effects detected in animal studies. When considered in } \\
\text { combination with its persistence and bioaccumulation } \\
\text { potential, the EPA determined dietary cancer risk from } \mathrm{HCH} \\
\text { was unacceptable. In addition, exposures to workers and } \\
\text { other persons applying BHC was of concern. Other countries } \\
\text { also noted persistence and bioaccumulation, high toxicity } \\
\text { and environmental effects as reasons for control actions. }\end{array}$ \\
\hline Heptachlor (1978) & Insecticide & $\begin{array}{l}\text { Heptachlor's toxicity to humans, other mammals, birds, fish } \\
\text { and other aquatic organisms, as well as a concern for } \\
\text { bio-accumulation, persistence and environmental } \\
\text { contamination. Of particular concern is Heptachlor's } \\
\text { demonstrated carcinogenic response in laboratory rodents } \\
\text { and its potential impact on human health from widespread } \\
\text { environmental contamination in the food chain. }\end{array}$ \\
\hline Hexachlorobenzene (1984) & Seed protectant & $\begin{array}{l}\text { Probable human carcinogen. HCB is also extremely } \\
\text { persistent in the environment. Residues have been found in } \\
\text { aquatic and terrestrial species, including in mankind. } \\
\text { Particularly high levels have been found in certain fish } \\
\text { species. The EPA has also expressed concern over the } \\
\text { possibility of HCB causing reproductive effects in wildlife } \\
\text { exposed to frequent or continuous low levels of the } \\
\text { compound. This concern is especially focused on carnivores } \\
\text { and higher mammals. }\end{array}$ \\
\hline Lindane (2002) & Acaracide/insecticide & $\begin{array}{l}\text { Persistency in the environment, bioaccumulation in the food } \\
\text { chain and toxicity to humans, aquatic and terrestrial } \\
\text { species. }\end{array}$ \\
\hline Mercury compounds (1976) & Many & $\begin{array}{l}\text { Toxic to humans. In addition, various forms of mercury are } \\
\text { toxic to aquatic organisms, and residues accumulate in the } \\
\text { aquatic biota with the result that potentially dangerous } \\
\text { residue levels are reached in aquatic foods consumed by } \\
\text { humans. }\end{array}$ \\
\hline Monocrotophos (1988) & Acaracide/insecticide/miticide & High mammalian toxicity. \\
\hline Pentachlorophenol (2005) & Wood preservative & Negative effects on non-target organisms. \\
\hline Toxaphene (1987) & Insecticide & $\begin{array}{l}\text { Acute oral toxicity and carcinogenicity in humans, population } \\
\text { reductions of non-target species, acute toxicology to aquatic } \\
\text { organisms, and chronic and/or delayed effects to aquatic, } \\
\text { avian, and mammalian species. In addition, toxaphene } \\
\text { bioaccumulates. }\end{array}$ \\
\hline
\end{tabular}


Table 2. Specifically Regulated Pesticides in Florida.

\begin{tabular}{|l|l|l||}
\hline \hline Active ingredient & Use & Criteria for regulation \\
\hline Aldicarb & Acaracide/insecticide/nematicide & Acute toxicity and groundwater contamination concerns. \\
\hline Bromacil & Herbicide & $\begin{array}{l}\text { Potential groundwater contaminant due to high mobility in } \\
\text { sandy, low-organic-matter soils. }\end{array}$ \\
\hline Methyl bromide & Fumigant & High acute toxicity. \\
\hline Organo-auxin herbicides & Herbicide & $\begin{array}{l}\text { Potential off-target drift and subsequent damage to sensitive } \\
\text { crops and other plants. }\end{array}$ \\
\hline Organotin antifouling paints & Algaecide & Toxicity to nontarget aquatic organisms. \\
\hline \hline
\end{tabular}

